Euskal ikerketen aldizkaria | Revue d'études basques |

Revista de estudios vascos | Basque studies review

$15 \mid 2011$

Numéro XV

\title{
Bokal sudurkariak gaurko lapurteran
}

\section{Oroitz Jauregi et Irantzu Epelde}

URL : http://journals.openedition.org/lapurdum/2316

DOI : $10.4000 /$ lapurdum.2316

ISSN : 1965-0655

Éditeur

IKER

Édition imprimée

Date de publication : 1 octobre 2011

Pagination : $29-42$

ISSN : 1273-3830

Référence électronique

Oroitz Jauregi eta Irantzu Epelde, « Bokal sudurkariak gaurko lapurteran », Lapurdum [Linean],

15 | 2011, Sarean emana----an 15 octobre 2014, kontsultatu 19 avril 2019. URL : http://

journals.openedition.org/lapurdum/2316 ; DOI : 10.4000/lapurdum.2316 


\title{
Bokal sudurkariak gaurko lapurteran*
}

\author{
Oroitz JAUREGI \& Irantzu EPELDE \\ Euskal Herriko Unibertsitatea (UPV/EHU), Iker (UMR 5478)
}

\begin{abstract}
Erkidego elebidunetan bi hizkuntzek elkarri nola eragiten dioten ikusiz (funtsean, gure kasuan, hizkuntza nagusiak — gaztelaniak edo frantsesak- euskaran nola eragiten duen), hizkuntza hartzailearen jokamoldeak neur ditzakegu, hark baliatzen dituen bilakaerak eta baliabideak azaltzeko. Ipar Euskal Herriko hizkera batean ikusi nahi izan dugu, oraingoan, hori nola gertatzen den. Ez da lan honen helburua Iparraldeko gaur egungo euskaran frantsesezko maileguak hartzerakoan joera nagusiak zein diren aztertzea, baina bai fonologia ezaugarri jakin baten bitartez gertatzen ari den berrikuntza bat azaltzea: frantsesak bokal ahokariez gain bokal sudurkariak ere badituenez, ikusi nahi izan dugu frantsesezko hitzak mailegatzerakoan euskaraz —lapurteraz- bokal sudurkariak gordetzen diren edo, berezkoa zaion sistemaren arabera, bokal horiek ahokari bihurtzen dituen.
\end{abstract}

\section{Sarrera}

Egungo euskarazko fonologia sistema bost bokal ahokarik osatzen dutela esan ohi da (Mitxelena 1990 [1961], Hualde 1991, Oñederra 2001 eta 2004b), zuberera ez beste gainerako euskal hizkerak kontuan hartuta, eta oro har bokal sudurkaririk ez dagoela, zubereraz izan ezik. Jakina da lehenago bazterreko euskalkietan balio fonologikoa zutela: erronkarieran gertatzen ziren bokal eta diptongo sudurkariak, eta duela zenbait mende baita bizkaiera zaharrean ere (hamaseigarren mendean dokumentatuta dago, Madariagaren Honra de Escriuanos horren lekuko) $)^{1}$.

Gure azterketaren abiapuntua izan da Ipar Euskal Herriko hizkeretan bokal sudurkari

\footnotetext{
* Gure esker ona azaldu nahi diegu esperimentuan parte hartu duten berriemaileei eta emaitzak papereratzerakoan aholkatu eta lagundu gaituzten lankideei: Honorine Chipy, Anne Bereau-Ibarra, Louis Ithourria, Henri Duhau, Ioritz Laxague, Beñat Oyharçabal, Lourdes Oñederra eta Jasone Salaberria.

1. Madariaga arratiarra zen, eta honela idatzi zuen arestian aipatutako 1565eko lan horretan: «La N algunas veces se pronuncia escondida en las narices, como en oracioa, Ardaoa, y para denotar aquella $n$ se deue sobre poner una cifra de esta manera a modo de nariz ^».
} 
berriak agertzen ari direla ohartzea, orain arte ahokari ahoskatzen ziren inguruneetan. Hipotesia da frantsesarekiko hizkuntza ukipenaren ondorioz sortu dela berrikuntza hau². Izan ere, frantsesak bere hots biltegian bi bokal motak ditu, eta, ondorioz, frantses hiztunak gai dira berariaz bokal ahokariak nahiz sudurkariak erabiltzeko, egungo frantsesean azken horiek galtzeko joera dagoen arren (Durand et alii 2002-).

Azken urteetan Lapurdin egindako alor lanean belarriz hauteman duguna esperimentalki neurtu nahi izan dugu hemen, eta horretarako hiztun lapurtarren jokamoldeari begiratu diogu. Oraingoan, lapurterazko datuetara mugatzea erabaki dugu, eta Lapurdi barruan Senpereko berriemaileak hautatu ditugu. Lapurteraz bokal sudurkariak zenbateraino ebakitzen diren ikusi nahi izan dugu honela, datu akustikoak erabiliz.

Gure argudioetarako, kontuan hartu beharreko ezinbesteko datua da lapurteraz ari diren hiztun guztiak elebidunak direla gaur egun. Hiztun elebidunak —elebidun goiztiarra bada-, bere erkidegoko bi hizkuntzen sistema fonologikoak menderatzen ditu (euskara eta frantsesa, gure kasuan). Aipatu dugu frantsesak, euskarak ez bezala, bokal sudurkariak dituela sistema fonologikoan (sudurkariek frantsesaren historian izan duten bilakaeraz, ik. Martinet 1965). Beraz, elebidun goiztiarrak bokal ahokariak nahiz sudurkariak fisiologikoki ekoizten ikasten du. Besterik da hizkuntza bakoitzean bata edo bestea erabiltzea (alegia, euskaraz bokal ahokariak eta frantsesez, berriz, ahokariak nahiz sudurkariak erabiltzen ikastea).

Arestian aipatu bezala, orain arteko alor lanetan belarriz hautemandakoa esperimentalki frogatu nahi izan dugu: hizkera lapurtar honetako hiztunak, euskaraz ari denean eta frantsesezko maileguak erabiltzen dituenean, bokal sudurkariak ekoizten ote ditu? Horrek berez bezala ekarriko luke lapurterazko euskara-frantsesa elebidun goiztiarrak [bokalak $\rightarrow$ ahokari] egiten dituen bilakabidea gainditua duela eta, horren arabera, hiztuna gai litzateke bi bokal motak berariaz ekoizteko, fonemikoki ebakitzeko, nahiz gero zein-noiz egin aukeratzeko gaitasun osoa izan.

Fonologia Naturala oinarri hartuta, aztergai izan dugun herrian — Senperen- bokal sudurkariak egiteko zailtasunik ez dutela argudiatuko dugu ondorengo atalean. Jarraian, egungo hiztunen ekoizpen grabatuak erabiliz, datu akustikoen bidez ikusiko dugu lapurteraz bokal sudurkariak unitate fonemiko gisa egiten diren edo ez. Horretarako, frantsesetiko maileguetan gertatzen diren bokal sudurkariak eta euskarazko hitzetan gertatzen diren sudurkaritzeak akustikoki neurtuko ditugu.

\section{Joera edo bilakabide natural unibertsalak gaindituz}

Fonologia Naturalak eskaintzen duen marko teorikoa — batez ere bilakabideen erabileraezinbesteko lanabesa iruditzen zaigu, bokal ahokarien eta sudurkarien afera muin-muinetik heltzen duelako.

Gure hizkuntza natiboaren fonologia sistema da bilakabideen sistema unibertsal baten

2. Lan honetan ez gara arituko forma ez-mailegatuen ahoskeraz, maileguen ahoskeran erabiltzen diren unitateez baizik. Guk maileguetan fonologia sistemaren aukerak nola aldatzen diren ikusi nahi izan dugu hemen, [bokal $\longrightarrow$ ahokari edo sudurkari] sistema baten alde, lapurteraz behintzat (lehenago ez bezala, [bokal $\longrightarrow$ ahokari] baitzen aukera bakarra hizkera honetan eta beste euskal hizkera gehienetan). 
ondorioa. Bilakabide hauek haurraren hizkuntza-xalotasun garaiko (edo, bestela esanda, hizkuntza ezagutzarik ez duen aldiko) baldintza edo muga fonetikoak islatzen dituzte. Language-innocent state litzateke ingelesezko terminoa, hau da, haurrak hizkuntzarekin eskarmenturik ez dueneko garaia. Pixkanaka, joera edo bilakabide natural unibertsal hauek mugatuz joaten gara, eta beste batzuk gaindituz, gure sistema fonologikoa osatu arte. Fonologia Naturalean bilakabideak nola ulertzen diren azalduko dugu jarraian.

Bilakabidea, berez, zailtasun fonetikoei erantzuten dien eragiketa mentala da. Bilakabidean hots batek zerbaitengatik zailagoa den beste bat ordezkatzen du, alegia, hots baten ordez beste bat ahoskatzen da, eta ordezkatzearen arrazoia fonetikoa da. Hizketaren izaera fisikoak bilakabideak eragiten ditu: hizketaren ezaugarri neuro-fisiologikoek, morfologikoek ${ }^{3}$, mekanikoek, denborazkoek eta akustikoek. Ezaugarri hauek sortzen dituzten zailtasunen erantzun dira bilakabideak.

Bilakabideak, esan bezala, hots ordezkatzeak dira, eta hots ordezkatzearen azalpena sinkronikoki fonetikak eman dezake, fonetikoki azal daiteke. Esan behar da izan daitezkeela ingurunedunak edo ingurunez landakoak. Bilakabide ingurunez landakoen emaitza dena delako hizkuntzaren hots-unitateak edo fonemak dira, inguruko hotsen eraginik eta erreferentziarik gabe gertatzen direlako. Hau da, [bokalak $\rightarrow$ ahokari] bilakabidean inguruneak ez du eraginik bilakabide horren gertaeran. Fonologia Naturalaren ekarpena izan da oinarrizko unitateen zio fonetikoa euskarri izatea, edo, bestela esanda, fonema sistemaren edo paradigmaren arrazoi fonetikoa bilatzea, eta arrazoi fonetikoan oinarritzea.

Bilakabide ingurunedunak dira, bestalde, ingurunea kontuan hartzen dutenak (ordezkatzea ingurune batean gertatzen denean). Lanaren muga fisikoa dela eta, oraingoan ez ditugu bilakabide mota horiek sakon azalduko.

Gure gaia muin-muinetik ukitzen duen bilakabide batek bokal guztiak ahokari egiten ditu. Oharmenaren eta ahoskagarritasunaren aldetik idealena bokalak ahokari izatea da. Hizketarako biriketatik datorren airea ahotik kanporatzea errazagoa da sudurretik kanporatzea baino, sudurretik kanporatzeak zailtasuna baitakar. Gertaera hau unibertsala da. Ahosabai bigunak eta bere luzakin haragitsuak, ahots-gingilak, sudurrerako bidea irekita uzten dutenean ahotsa ateratzen bada, orduan hots sudurkariak ekoizten dira (Oñederra 2004b: 142). Bokal sudurkariak ekoiztea bokal ahokariak ekoiztea baino konplexuagoa da fisikoki. Ahotsa sudurretik kanporatzeko ahots-gingilak lan egin behar du, eta ahots-gingila kontrolatzeak zailtasuna dakar. Zailtasun hori gainditzeak ematen dio gaitasuna hiztunari bokal sudurkariak nahita ebakitzeko ${ }^{4}$.

Egungo euskaraz, oro har, bokal guztiak ahokari egiten dituen bilakabidea indarrean dago, eta bokalak ahokariak ditugu euskaraz (zubereraz izan ezik). Frantsesak zailtasun fonetiko hori gainditua duenez, bokal ahokariez gain bokal sudurkariak ere baditu fonemikoki. Bilakabideari amore emateak esan nahi du paradigman unitate gehiago edukitzea. Frantsesa

3. Zentzu ez-gramatikalean.

4. Romaine-k dio hiztunek aski aise alda dezaketela, esate baterako, beraien pragmatika, baina nahita egindako aldaketak fonetikan sartzea askoz nekezagoa dela (1996: 111). Hiztunek nahita egiten dituzten hizkuntza aldaketez, ik. Thomason 2007. 
ikasi behar duen haur batek [bokal $\rightarrow$ ahokari] bilakabidea gainditu beharko du, bilakabide hori egokitu egin beharko du. Bokal sudurkariak egiteak sortarazten duen zailtasuna da gainditu beharko duena, eta bokalak —ahokariak nahiz sudurkariak— nahita ekoizten eta erabiltzen ikasi beharko du. Behin zailtasun hori gaindituta, frantses hiztunak gai dira berariaz bokal ahokariak nahiz sudurkariak erabiltzeko. Gauza bera esan daiteke Iparraldeko elebidun goiztiarrez ere.

Hizketan hotsak bata bestearekin kateatzean nahitaez koartikulazioa gertatzen da, hau da, hotsak bata bestearekin kateatzea eta askotan ezaugarriak teorian ditugunak bezain finko eta bereiziak ez izatea. Halaxe gertatzen da sudurkaritzearekin ere:

A nasal consonant is produced with a velopharyngeal opening but with a complete closure of the main vocal tract at some point within the oral cavity. (...) When a nasal consonant occurs adjacent to a vowel, there is usually some opening of the velopharyngeal port and hence some nasalization in at least part of the vowel adjacent to a consonant. (Stevens, 1998: 305)

Izan ere, bokala ingurune sudurkarian sudurkaritu egin ohi da; neurri handiagoan edo txikiagoan, baina sudurkaritzea gertatzen da. Kasu honetan hiztunak ez du nahita egiten sudurkaritzea, inguruneak eraginda baizik, eta bere inbentarioan ez dagoenez bokal sudurkaririk, ez da gai ez hots hori hautemateko, ezta nahita egiteko ere (ikasi ezean behintzat), baina ekoitzi egiten du, inguruneak eraginda. Hots horiei alofono esaten zaie. Hurbilketa honetako azterketa akustikoan kasu horiek ere neurtu ditugu, ikusteko euskarazko hitzetan sudurkaritzea gertatzen ote den, eta bi unitate (bokala eta sudurkaria) edo bakarra ekoizten ote den.

Sudurkaritze testuinguruei begiratzen badiegu, sudurkaritasuna gertatzeko ingurune errazena da silaba amaieran kontsonante sudurkaria dagoenean (bereziki hitzaren azken silaba bada), eta kontsonante sudurkari horren aurretik bokala dagoenean. ${ }^{5}$ Coda (silaba-azkeneko kontsonante edo kontsonante multzoa) ahulagoa da ekina baino.

\section{Esperimentua}

Ikerketa akustikoa egiteko, lau hiztun hautatu ditugu, laurak Senperekoak: hiru adinekoak (80, 86 eta 89 urte) eta gazte bat (28 urte). ${ }^{6}$ Bosgarren hiztun bat ere baliatu dugu

5. Dirudienez, gaztelaniaz sudurkaritze mota horretan bokala sudurkariago izan ohi da adibidez frantsesez baino. Frantsesezko bokal sistemak bokal ahokariak eta sudurkariak ditu eta gaztelaniak bokal ahokariak. Frantsesez sintagmatikoki gertatzen den sudurkaritze bilakabidean bi bokal mota horiek nolabait bereizi egiten dira, eta beste zenbait hizkuntzatan gertatzen den sudurkaritze maila baino apalagoa antzeman daiteke.

6. Galdeketa osoagoa izateko berriemaile gehiago eta adinean aniztasun handiagoa beharko litzateke, baina mementoan hurbilketa bat egin asmo genuen esperimentu honekin. Era berean, sudurkaritasuna neurtzeko sudurretik ateratzen den airea ( «nasal flow») neurtzea erabat lagungarria izango litzateke, baina horretarako Fonetika Laborategian gauzatu beharko litzateke datu bilketa (lekuko gehienen adina kontuan hartuta ez da erraza), eta, horrez gain, aparailu berezi bat beharko litzateke (EHUko Letren Fakultateko Fonetika Laborategian oraingoz ez da halako tresnarik). 
datuak egiaztatzeko, baina haren ekoizpenen uhinik ez dugu erabili. Grabaketak hiztunen etxeetan egin dira ${ }^{7}$ 2008ko udan eta 2010ean zehar, Sony MD Walkman eta Sony ECM-717 mikrofono aparailuekin. Grabatutako seinalea ordenagailura M-Audio-ren bidez pasatu eta gero, neurketak PRAAT programarekin egin ditugu. Azterketa akustikoa egiteko hots uhina eta espektrograma erabili ditugu.

Galdeketak egiteko, hitz zerrenda bana aurkeztu genien hiztunei frantsesezko hamarna hitzekin, eta horiek euskaraz emateko eskatu. Euskaraz arruntki erabiltzen dira hitz horiek guztiak. Ondoren, euskarazko 10 hitzeko zerrenda bana aurkeztu genien, eta horiek ozenki esateko eskatu. ${ }^{8}$ Euskarazko hitz guztietan (C)VN. ${ }^{9}$ bilkura lehenengo silaban dago, ez dago bat ere hitz amaieran duenik. Frantsesetiko maileguetan ere agertzen da bokal sudurkaria lehenengo silaban, adibidez ambulance, invitation eta symphonie hitzetan; amaieran dutenek askotan beste kontsonante bat ere badute jarraian, adibidez science, lampe, pompe, bombe. Hau da, sudurkaria ez dago erabateko amaieran. Hurrengo galdeketa eta neurketetarako utziko dugu aldaera hauek guztiak kontuan hartzea.

Kontrol hitzak ere aztertu ditugu, eta horiek lortzeko hizketa librea erabili da. Aztertu beharreko hitzak grabatu ondoren, hiztunen hizketaldi libreak grabatu genituen, eta bat-bateko molde horretatik hautatu dira kontrol hitzak. Beraz, hiztun bakoitzeko 20 item izango ditugu, guztira 40 item, eta horien ondoan kontrol hitzak ( 5 hiztun bakoitzeko), besteen osagarri.

Frantsesetiko maileguetako bokal sudurkarien ezaugarri akustikoak aztertu eta neurtu ditugu beraz, frantsesezko bokal sudurkariak euskarazko jardunean nola ekoizten diren ikusteko. Frantsesez eta beste zenbait hizkuntzatan (portugesez, kasu) (C)VN. testuinguruan kontsonante sudurkaria aurreko bokala sudurkaritu ondoren desagertu egiten da. Gertaera hori diakronikoki eta etengabe gertatzeak bokal sudurkariak sortzea ekarri du.

Euskarazko hitzetan, ingurune sudurkarian gertatzen diren sudurkaritzeak izango dira aztergaia, eta bi unitate (bokala eta kontsonante sudurkaria) edo bakarra (bokal sudurkari edo sudurkaritua) egiten den ikusiko dugu.

Azkenik, frantsesetiko maileguen atala osatzeko, NorANTz ${ }^{10}$ ikerketa egitasmoko Senpereko datuak ere erabili ditugu, 2010ean zehar senpertar adintsu bati (86 urte) eta gazte bati (28) egindako galdetegien soinuzko erantzunak aztertuz. Kasu honetan, perpaus labur batzuk euskaratzeko eskatu genien lekukoei. Hona hemen sudurkariei dagokien galdetegiko atala, eta lekuko bakoitzak eman zituen erantzunak, zaharrenetik gazteenera (egitasmoaren galdetegian erabili ziren kodeak gorde ditugu):

7. Jakinaren gainean gaude grabaketa egiteko ez dela egoerarik hoberena, baina lehentasuna eman diogu lekukoa eroso sentitzeari.

8. Esperimentuaren diseinuaren aldetik, eta bi hitz motak lortzeko metodo bera erabiltzearren, komeni zen beharbada euskarazko hitzak ahoskatzeko garaian ere frantsesezko ordainak ematea, gero hiztunek euskarazkoak eman zitzaten. Hartara bokal eta kontsonante sudurkari bilkura idatziz ikustea saihestuko genukeen. Guk bestela jokatzea hobetsi dugu, berriemaileei arinago gerta zekien.

9. Silaba bukaerako kontsonante sudurkaria adierazi nahi dugu N. honekin.

10. Egitasmo hori 2009-2011 bitartean gauzatu da IKER zentroan. Xehetasunetarako: www.norantz.org 
[ã]

F35- Il y a beaucoup d'Anglais cette année.

Angeles ainitz bada aurten.

Aurten ingles ainitz badira.

F36- J'aime beaucoup les endives.

Andivak maite ditut.

Endiviak asko maite ditut.

F37- Le sergent est très sympathique.

Sarienta arrunt goxoa da.

Serg[ã]ta arras sinpatikoa da.

F38- Les gendarmes sont venus.

Jandarmak etorri dire.

Jendarmeak etorri dira.

F39- Lampoule est cassée.

Anpula hautsi da.

Bonbila hautsia da.

F40- Donnez-moi une tranche de viande.

Aragi trantxa bat emadazu.

Eman nazazu aragi xer bat, otoi.

[õ]

F41- Je n'aime pas les conserves.

Kontserbak ez ditut maite.

Kontserbak eztitut maite.

F42- Ils ont appelé les pompiers.

Ponpierak galdein tuzte.

Suhiltzaileak deitu dituzte.

F43- Il n'a pas de conscience.

Kontzientziaik eztu.

$\underline{\mathrm{K}[o \tilde{l}}$ zientziaik eztu.

F44- Il est content.

Konten da.

Konten da.

$[\tilde{\varepsilon}]$ 
F45- La blessure s'est infectée.

Zauria gaxtatu zait.

Zauria infektatu da.

F46- J'ai appelé un infirmier.

$[\tilde{\varepsilon}]$ firmiera galdegin dut.

Erizain bat deitu dut.

F47- C'est intéressant.

Interesanta da.

Interesgarria da.

\section{Emaitzak}

Ondoren, gure datuetan oinarritutako emaitzak aurkeztuko ditugu. NoRANTz egitasmoari dagozkionak horien osagarri emango ditugu, 4.2. azpipuntuan bokal bakoitzari eskaini diogun atalean. Laburki esateko, proposatutako 20 kasuetatik 13tan, hau da, \%65etan bokal sudurkariak ekoitzi dituzte hiztunek. Ikus ditzagun xehetasunak:

4.1. Euskarazko hogei itemei dagokienez, ia kasu guztietan bi unitate gertatzen zirela erakutsi dute espektrogramek: bokala (sudurkaritze puntu batekin, hori handiagoa edo txikiagoa izan) eta kontsonante sudurkaria. Adibidez: kanbiatu, kankaila 'kankailua', kanpotiarra, ganbara 'gela', kanta. Batzuetan lehen silabako CVN. testuinguruan bi unitate osatzen zuten nabarmen lehenengo a bokalak eta honen segidan datorren kontsonante sudurkariak. Gauza bera gainerako bokalez osatutako adibideetan ere. Euskarazko hitzak aztertzean, hortaz, eta teoriak esaten duena baieztatuz, bokalen sudurkaritzea antzeman daiteke ia kasu guztietan, baina gehienetan bi unitate — bokala eta sudurkaria — garbi antzematen dira espektrograman. Horren garbi antzematen ez denean, bokala sudurkaritu egiten dela esan daiteke, ${ }^{11}$ ondoko irudian ikus daitekee moduan.

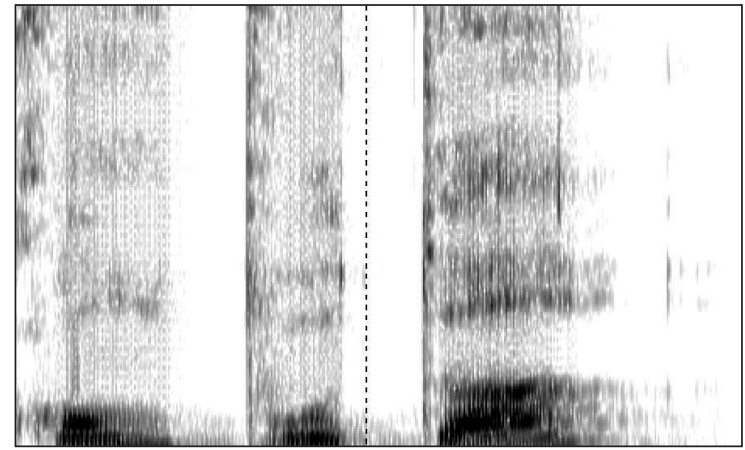

1. irudia: Euskarazko konpota hitzaren espektrograma irudia.

11. Azterketa sakonagoak egin beharko lirateke euskarazko hitzen inguruan. 
4.2. Frantsesezko 20 itemak euskaraz esan ohi dituzten bezala ahoskatzeko eskatzerako, jakitun ginen galdetegian hitzak frantsesez idatzita ikusteak zekarren efektuaz. Dena dela, hizketa librean egiaztatu ahal izan dugu adibideon ohiko ahoskera, eta bat zetorren hitz zerrenden grabazioetan jasotakoarekin.

4.2.1. Kontuan izan behar dugu erreferentziatzat hartu ditugun frantsesezko hiru bokal

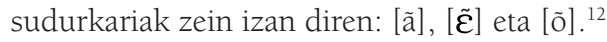

[ã] ahoskatu dituzte banka 'bankua' (fr. banque), antretenitu 'mantendu, zaindu' (fr. entretenir) edo tanzionia 'tentsioa' (fr. tension) bezalako hitzak, eta uhinetan unitate bakar moduan agertzen dira idatziz a bokala eta kontsonante sudurkaria agertzen dena (bokala sudurkaritzean kontsonantea desagertzen baita).

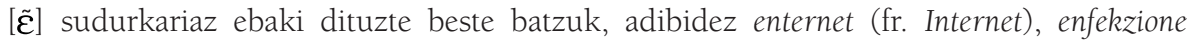
'infekzioa' (fr. infection) edo zenfonia 'sinfonia' (fr. symphonie) (ik. 2. eta 3. irudiak).

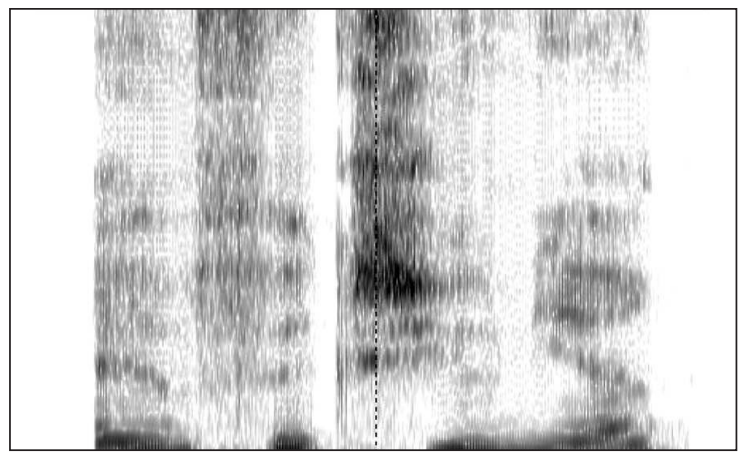

2. irudia: Enfekzione maileguaren espektrograma irudia (fr. infection).

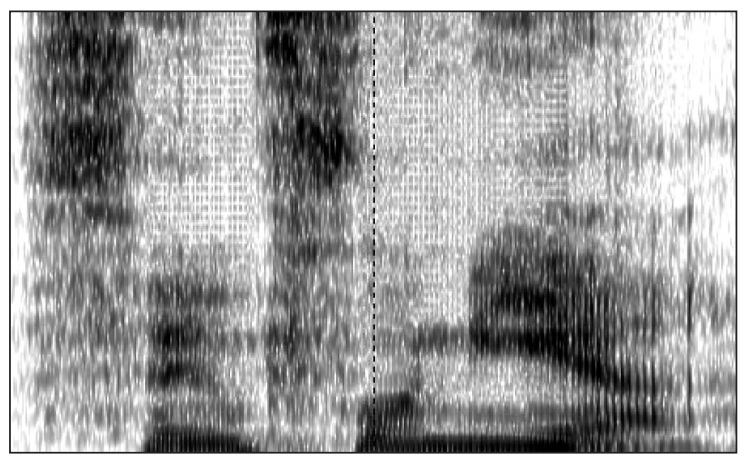

3. irudia: Zenfonia maileguaren espektrograma irudia (fr. symphonie).

Aldiz, zenbait hitzekin tarteko bilakaera bat ikusi dugu. Kasu honetan, adibidez, bokalaren sudurkaritzea ez da bururaino eraman: zendikata 'sindikatua' (fr. syndicat) ahoskatu

12. [õe] sudurkaritua ez dugu kontuan hartu gure azterketan. 
du berriemaileak, baina lehen silabako bokala sudurkaritzera iritsi gabe, hau da, bi unitate gordez. Frantsesezko impôt 'zerga' hitzean, ordea, in- espero genuen hitz hasieran ${ }^{13}$, baina berriemaileak enposak ahoskatu du lehen silaban frantsesezko $[\tilde{\varepsilon}]$ bokal sudurkaria gordez.

Hirugarren bokalari dagokionez, [õ] ebakera izan da, esaterako, honako adibide honetan: ponpierak 'suhiltzaileak' (fr. pompier).

4.2.2. Azkenik, bi unitate eginez [bokala (neurri handiagoan edo txikiagoan sudurkaritua) + kontsonante sudurkaria] ebaki dituzte, uhin espektrografikoen arabera, beste zenbait adibide (20tik 7): lanpa 'lanpara' (fr. lampe), anpronta 'mailegua' (fr. emprunt) hitzeko lehen silaba, manta 'menta' (fr. menthe) (ik. 4. irudia), zantimetra 'zentimetroa' (fr. centimètre), intresak 'interesak' (fr. intérêt), bonba 'lehergailua' (fr. bombe) eta arrunda 'biribila' (fr. rond). Azken adibidean, gainera, ikus daiteke nola egokitu den mailegua euskararen arauen arabera, hitz hasierako bokal protesiaz gain ekialdeko hizkeretan ohikoa den bilakaera bat gertatu baita: $o$ $>$ ixtea kontsonante sudurkariaren aurretik. Mailegu egokitzearen aldetik berezia da intresak ere (fr. intérêt) (ik. 5. irudia), impôt hitzean bezala euskaraz kontsonante txistukaria agerian duelako (mailegu zaharrak dira bata zein bestea).

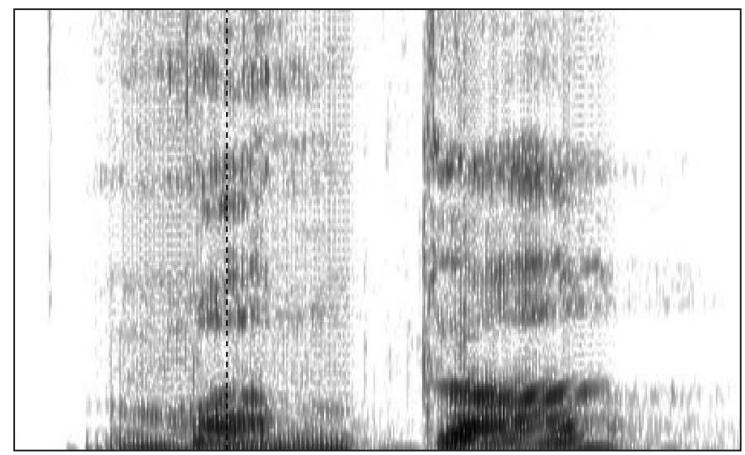

4. irudia: Manta 'menta' maileguaren espektrograma irudia (fr. menthe).

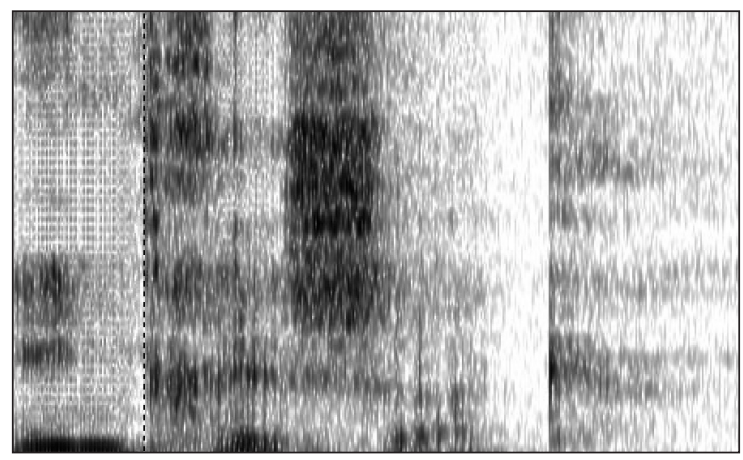

5. irudia: Intresak 'interesak' maileguaren espektrograma irudia.

13. Inposak da lapurteraz (bigarren silabako txistukaria agerian gelditzen da, mailegu zaharretan bezala). 
Bestalde, aipatu behar da aldakortasuna oso kontuan hartu beharreko datua dela, baita hiztun beraren barne aldakortasuna ere. Adibidez, [ã]nvelopa ahoskatu zuen gure berriemaileak, baina beste hiztun batzuen ahotik entzun izan dugu euskararen arauen arabera egokituta mailegu hori: enbelopa, $[v]>[b]$ bilakatuz eta are [emelopa] ebakiz, askotan sudurkariak asimilatzen duelako ondoko herskaria $<\mathrm{mb}>$ eta $<\mathrm{nd}>$ taldeetan: lemiziko 'lehenbiziko', demora 'denbora', zomait 'zenbait', zomat 'zenbat', amertze 'hainbertze'... Imitorio 'inbentarioa' mailegu zaharrean ere aurki dezakegu $n b>m$ idazle klasikoetan (ik. OEH, imitorio sarrera), baina gaurko joera nagusia frantsesez bezala ahoskatzea da: $[e] n[v]$ antera (fr. inventaire) ahoskatu du gure berriemaileak.

Maileguaren antzinatasuna erabakigarria dela ikusten da egokitze graduari dagokionez. Oro har, mailegu zaharretan euskararen fonologia arauen arabera egokitu dira hotsak, intresak mailegu zaharrean ${ }^{14}$ ikusi dugun bezala. Linja (fr. linge) eta xinplea (fr. simple) ildo bereko adibideak izango lirateke (ez dira sudurkaritzen eta unitate bakarrean biltzen). Bestalde, gaineratu daiteke joera zaharra izan daitekeela lehenengo silabako bokala, hau da, frantsesezko

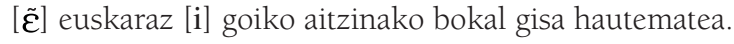

Maileguaren antzinatasuna zenbateraino den erabakigarri oso garbi ikusten da NoRANTz egitasmoaren bitartez lortu eta 3. atalean aurkeztu ditugun erantzunetan, eta baita hiztun zahar/ gazte kontrastea ere, mailegu zaharrak eta berriak erabiltzerakoan. Berriemaile zaharrenak,

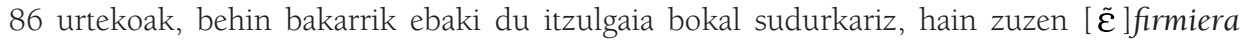
'erizaina' hitzean. Gazteak, pentsatzekoa zenez, ikasia du euskarazko ordain berria (18 urte arte ikastolan ibilia da), eta, espero genuen bezala, erizaina itzuli du. Gauza bera gertatu da anpula/bonbila, trantxa/xerra eta ponpierak/suhiltzaileak pareekin.

Bestalde, gorago ikusi bezala, mailegu zaharrak euskararen fonologia arauen arabera emateko aspaldiko joera guztiz konfirmatzen da Norantz egitasmoko bi lekuko senpertarretan zaharrenaren jokabidea ikusita. Garbi ikusten da kontrastea bi adibide hauekin: gazteak bokal sudurkariz ebaki dituen bi mailegu zahar (serg[ã]ta 'sanjentua' etak[õ]zientziaik 'kontzientziarik') erabat euskararen fonologiaren arabera eman ditu adinekoak: sarienta mailegu egokituarekin, alde batetik, eta kontzientziarik osoki eta aspaldi euskaratutakoarekin, bestetik. Besterik da, ikus daitekeenez, gaztearen jokabidea mailegu zaharrok hartzeko orduan eta moduan.

\section{Hizkuntza ukipenaren ondorioak Iparraldeko ahoskeran}

Ukipen egoeretan gertatzen diren bilakaerak aztertzeko egoera egokia dugu Euskal Herrian, bai Hegoaldean eta bai Iparraldean. Lehenean, gaztelaniazko maileguak euskarak fonologikoki nola egokitzen dituen ikertu dute berriki zenbait euskalarik —adibidez, Hualde (2000) eta Oñederra (2009)_, eta euskarak Hegoaldeko elebidunen gaztelaniazko fonologian nolako eragina duen ere aztertu izan da (Echaide 1966, Oñederra 2001 eta 2004a). Gai honen inguruan oso ikerketa gutxi egin da Iparraldeko hizkerei dagokienez (Epelde 2011).

Guk frantsesa-euskara ukipen egoera hartu dugu lan honetan, eta eraginaren nondik norakoak ikusteko muga inguruko hizkera bat hautatu dugu. Frantsesezko hitz mailegatuak oso ugariak dira Senpereko mintzoan (eta Iparraldean, oro har). Hiztegian arreta jarriz gero,

14. XVI-XVII. mendeetan interes erabiltzen zen Iparraldean, baina XVIII.etik aurrera intres indar handiagoz zabaldu da (ik. OEH, interes sarrera). 
ikusiko dugu maileguak egokitzerakoan hiztun tradizionalek segitzen zituzten urratsak askotan ez dituztela betetzen gaur egungoek, eta mailegu horiek euskal arauen arabera egokitu ordez bere horretan uzten dituztela maiz. Askotan, frantsesezko maileguak aurkitzen ditugu, euskararen hiztegian dagoeneko baziren hitzen ordainetan. Baina hizkuntza batek besteari —nagusiak azpikoari- pasatzen diona lexikoa baino gehiago da. Hemen aztergai dugun fonologiazko berrikuntza oraintxe gertatzen ari da, dinamika «bizia» da (Labov 2001: 498500), eta hizkuntzaren baitan ere aldaketa baten sorburua izan daiteke. Horren seinale da datuetan ageri den aldakortasuna, bai belaunaldien arteko aldakortasuna, baita hiztun beraren baitan ikus daitekeena ere.

Hizkuntza batetik bestera zer iragaten den eta zer ez asko eztabaidatu izan da hizkuntza kontaktuaren gaineko literaturan. Aditu batzuen ustez (Weinreich 1974, Givón 1979, Bickerton 1981 eta Silva-Corvalán 1992, beste batzuen artean), hizkuntza hartzailean gertatzen diren aldaketek azaleko egiturari eragiten diote soilik, ez dira iristen barne egiturara. Guri dagokigun adibide bat jartzeagatik, eman dezagun Iparraldean dardarkariarekin gertatzen dena: berezko ebakera hobikariaren ordez, ebakera ubularra nagusitu da ia erabat gaur egungo hiztun elebidunen artean euskarazko hitzetan ere (adin handiko zenbait hiztunetan ez beste guztietan), eta beraz lerratze nabarmena izan da hor, jadanik euskararen hots sisteman bazen fonema bati zuzenean eragiten diona. Aldi berean, ahoskera hori ubularrera lerratzearekin batera, hots bat (dardarkari hobikaria) galdu da Iparraldeko euskaran (esan bezala, adin handiko hiztun batzuetan izan ezik). Sapir-en tesia da (1921) muturreko egoera soziolinguistiko berezietan ez bada, hizkuntza batetik bestera iragaten dena azalekoa izaten dela (hitzen ordena, mailegu lexikoak, kalkoak eta abar), eta hizkuntza hartzaileak hura egokitzeko baliabideak moldatu egiten dituela.

Ordea, esperimentu honen emaitzek erakutsi digutenaren arabera, bokal sudurkariak eremu horretako euskararen hots sisteman sartzen ari badira ${ }^{15}$, orduan aldaketa beste norabide batean gertatzen ariko litzateke, orain arteko euskararen hots biltegian ez zeuden fonema berriak sartzen ariko liratekeelako.

Maileguen egokitzeari erreparatuz, ikas genezake fonologia sistemaren aukerak nola aldatzen ari diren, zer bilakaeraren alde egiten duen euskarak hots arrotzak ebaki behar dituenean, eta zenbateraino moldatzen dituen bere arau propioen arabera. Uste dugu Heinek eta Kutevak gramatika kategorietarako azaldu izan duten fenomenoaren antzekoa gerta litekeela hemen fonologiaren alorrean:

Contact situations, except for cases of attrition, tend to lead not to the reduction and loss of existing grammatical categories, but rather to diversification and to the creation of new grammatical categories in one language on the model of another language. (Heine \& Kuteva 2005: 258)

Hau guztia ikusita, esan dezakegu hotsak desagertzen baino gehiago berriak agertzen ari direla aztergai dugun hizkeran.

15. Zehaztu behar da maileguei eragiten dien gertakaria dela. 


\section{Ondorioak}

Hitz eta elementu arrotzak ahoskatzeko garaian ikertzen badugu hizkuntza hartzaileek nola jokatu ohi duten, ikusiko dugu hitzok mailegatzeak automatikoki nolabaiteko egokitze fonetikoa ekartzen duela, hizkuntza edozein dela ere. Beti egongo dira hots arrotzak edo hizkuntza hartzaileak ez dituen bestelako berezitasunak, are gehiago gure kasuan bezala tipologikoki desberdinak badira. Kontua da nola gertatzen den hori. Izan ere, berrikuntzak hartzerakoan erabakigarria izan daiteke peko hizkuntzak — gure kasuan euskara lapurtarraknagusiaren (frantsesaren) aldean daukan indar eskasia. Sapir-ek (1921) erakutsi zuen zein "egoskor" ager daitekeen hizkuntza bat maileguak fonetikoki itxuraldatzeko garaian, eta geroago baita Thomason-ek (2007) ere, fonetikaren esparrua gainditzen duten bestelako gertakarien bidez.

Oso aurrean izan behar dugu zenbateraino aldatu den aztergai dugun erkidegoko egoera soziolinguistikoa eta zein den oraingo elementu berria: elebidun goiztiarren erabateko ugaltzea. Bi hizkuntzak batera ikasten dituenak bi mintzaira horiek eskatzen dituzten bilakabideak gainditu beharko ditu, bai frantsesarenak eta bai euskararenak. Euskarak frantsesak baino bilakabide oinarrizkoagoak ditu. Beste hitz batzuekin esanda, frantsesak baino unitate gutxiago ditu hots biltegian. Bi hizkuntzak batera ikastean — areago oraindik lehendabizi euskara eta gero frantsesa ikasten duenak-, euskararen bilakabideak gainditzeaz gain frantsesarenak ere gainditu behar ditu, beharrezkoa du aldaketa hori, frantsesetikako hitz mailegatuak egoki ahoskatuko baditu. Horrek eragiten du nahitaez aldatzea beste hizkuntzaren (euskararen) sistema fonologikoa (Oñederra 2009).

Berrikuntzek hiztunen solasean zenbaterainoko indarra eta hedadura hartzen duten beste gai bat da, hizkuntza jarrerekin-eta lotuta dagoena, baina maileguak jatorrizko hizkuntzaren ahoskera arauen arabera ahoskatzeko berrikuntza automatikoki hartuko du hiztunak. Berrikuntza horiek pisu handikoak izan daitezke, euskararen ezaugarri tipologikoak aldatzerainokoak.

Era berean, orain arteko euskal hizkera gehienen ezaugarria bada bost unitate bokaliko izatea eta orain maileguen bitartez seigarren bat sartzen ari dela — edo sartu dela— frogatuko bagenu (ü [y]), baieztatuko litzateke frantsesaren eraginez hor ere euskararen berezko ezaugarri bat (bost bokal izatea) aldatu den hipotesia. Mailegurik izango ez balitz, hori ez litzateke antzemango, hiztunak ez lukeelako hots horiek ekoitzi beharrik izango (nahiz eta delako hots hori ebakitzen jakin), baina maileguak hor dituenez eta beharrezko dituenez, agerian gelditzen dira hots berri horiek. Noiz gertatzen da, ordea, hori? Badirudi elebidunetan nerabezaroa mugarria dela bi hizkuntzez osoki jabetzeko bidean:

Gradually we constrain those processes which are not also applicable in the mature language (...). From adolescence usually there is little further change, and the residual processes have become the limits of our phonological universe, governing our pronunciation and perception even of foreign, invented, and spoonerized words, imposing a 'substratum' accent on languages we subsequently learn, and labeling us as to national, regional, and social origins. (Donegan \& Stampe 1979: 126-127)

Gaur egun, ama hizkuntza euskara duen edozein hiztun frantses hizkuntzaz ere nerabezaroa baino lehen jabetzen da Iparraldean, Hegoaldean gaztelaniarekin gertatzen den bezala. Haurrak txikitatik ikasten du frantsesezko hotsak fisikoki ekoizten, hots horien musikaz jabetu da 
hasieratik, eta ez dauka haiek ekoizteko eragozpenik. Hala esplika liteke, gure ustez, bokal sudurkarien berrikuntza hau ere.

\section{Erreferentziak}

Bickerton, D. 1981. Roots of Language. Ann Arbor: Karoma.

Calabrese, A. \& W. Leo Wetzels (arg.). 2009. Loan phonology. Amsterdam: John Benjamins.

Donegan, P. \& Stampe, D. 1979. "The Study of Natural Phonology". Current Approaches to Phonological Theory. Daniel A. Dinnsen (arg.), 126-173. Bloomington: Indiana University Press.

Donegan, P. 1985. On the Natural Phonology of Vowels. New York: Garland.

Durand, J., Laks, B. \& Lyche, C. 2002-. Phonologie du français contemporain: usages, variétés et structure (PFC). <http://www.projet-pfc.net>

Echaide, A. M. 1966. "Castellano y vasco en contacto: tendencias fonéticas vascas en el castellano de los vascohablantes bilingües". Boletín de la Real Academia Española 46, 513 523.

Epelde, I. 2011. "Lapurdiko itsasegiko euskararen ahoskera: Donibane Lohizune". 'Koldo Mitxelena' Katedraren Argitalpenak 4. Koldo Mitxelena Katedraren II. Biltzarra. VitoriaGasteiz: Euskal Herriko Unibertsitatea, 307-323.

Givón, T. 1979. "Prolegomena to any sane creology". Readings in Creole Studies. Ian F. Hancock (arg.). Ghent: Story Scientia.

Heine, B. \& Kuteva, T. 2005. Language Contact and Grammatical Change. Cambridge: Cambridge University Press.

Hualde, J. I. 1991. Basque phonology. London: Routledge.

Hualde, J. I. 2000. "Patterns of correspondence in the adaptation of Spanish borrowings in Basque". General Session and Parasession on Loan Word Phenomena: Proceedings of Twenty-Fifth Annual Meeting of the Berkeley Linguistics Society, 12-15 February 1999. S. Chang, S., Liaw, L. $\&$ Ruppenhofer, J. (arg.), 348-358. Berkeley: Berkeley Linguistic Society.

Huffman, M. \& R. Krakow (arg.). 1993. Nasals, Nasalization, and the Velum. San Diego \& London: Academic Press.

Labov, W. 2001. Principles of Linguistic Change. Vol. 2: Social Factors. Oxford: Blackwell.

Madariaga, P. 1565. Honra de Escriuanos. Valencia. 1565. Vid. J. de Urquijo, «Notas de bibliografía vasca. XIII. Pedro de Madariaga vizcayno, vascófilo», RIEV 13 (1922), 248-251.

Martinet, A. 1965. "Les voyelles nasales du français", La linguistique, 2. lib., 117-122.

Mitxelena, K. 1990 [1961]. Fonética Histórica Vasca. San Sebastián: Diputación Foral de Gipuzkoa.

Oñederra, M. L. 2001. "La cabeza es para andar: sobre el español hablado en zona vasca". Actas del V Congreso Internacional de Historia de la Lengua Española. Madril: Gredos. 263-273.

Oñederra, M.L. 2003. Palatalization revisited: bustidura adierazgarriaren estatusaz ohar batzuk. In X. Artiagoitia, P. Goenaga \& J.A. Lakarra (arg.). Erramu Boneta: Festschrift for Rudolf P.G. de Rijk. Bilbao: Euskal Herriko Unibertsitatea, 499-511.

Oñederra, M. L. 2004a. "El español en contacto con otras lenguas: español-vasco". In Historia de la Lengua Española. Barcelona: Ariel, 1103-1115.

Oñederra, M. L. 2004b. Fonetika-fonologia hitzez hitz. Bilbo: Euskal Herriko Unibertsitatea.

Oñederra, M. L. 2009, "Early bilingualism as a source of morphonological rules for the 
adaptation of loanwords: Spanish loanwords in Basque". In Calabrese, A. \& W. Leo Wetzels (arg.), 2009, 193-210.

Romaine, S. 1996. "The status of sociological models and categories in explaining language variation." Toward a critical sociolinguistics. Rajendra Singh (arg.). Amsterdam: John Benjamins.

Sapir, E. 1921. Language: An Introduction to the Study of Speech. New York: Harcourt Brace Jovanovich.

Silva-Corvalán, C. 1992. "On the permeability of grammars: Evidence from Spanish and English contact". Linguistic Perspectives on the Romance Languages, Sabih, W., Mithun, M., Perissinotto, G. \& Raposo, E. (arg.), Amsterdam \& Philadelphia: John Benjamins, 19-43. Stampe, D. 1979. A Dissertation on Natural Phonology. New York: Garland Publishing Co.

Stevens, K.N. 1998. Acoustic Phonetics. Cambridge \& London: MIT.

Thomason, S. 2007. "Language Contact and Deliberate Change". Journal of Language Contact 1: 41-62.

Weinreich, U. 1974. Languages in Contact: Problems and Findings. The Hague: Mouton [1. argitalpena: Linguistic Circle of New York, 1953]. 